\title{
THE SPRINGTAILS (INSECTA: COLLEMBOLA) FAUNA AT DIFFERENT MICROHABITATS OF BEČIĆI BEACH, MONTENEGRO
}

\author{
TATJANA R. JAKŠIĆ ${ }^{*}$, PREDRAG S. VASIĆ ${ }^{1}$, NENAD Đ. LABUS ${ }^{1}$, OLIVERA M. \\ PAPOVIĆ ${ }^{1}$, MILOŠ R. STANOJEVIĆ ${ }^{1}$, NIKOLA N. ĐUKIĆ ${ }^{1}$
}

${ }^{1}$ Faculty of Sciences and Mathematics, University of Pristina, Kosovska Mitrovica, Serbia

\begin{abstract}
Collembola fauna has been investigated at different microhabitats near the beach in Bečići, Montenegro. Samples were collected from four locations: Hotel "Tara", "Sveti Toma" Church (St. Thomas), Hotel "Naftagas" and "Zelena Stena" (Green Rock). Each of the location presented different microhabitat: under the palm tree, cypresses tree, larch tree and white pine tree. Samples were taken in May and September 2015 and results presented as qualitative findings.

Total number of 30 Collembola species was identified, classified into six families and 17 genera. Representatives of the family Hypogastruridae and Isotomidae were recorded at all of the studied sites, while representatives of the families: Naenuridae, Onychiuridae, Entomobryidae and Sminthuridae were present on some of locations.

The biggest number of species and the highest Collembola population density was found at the Green Stone site, 24 species in total, microhabitat- white pine, and the smallest number of species, 6 on site "St. Thomas" Church, microhabitat- cypresses trees.
\end{abstract}

Keywords: Collembola, microhabitats, Bečići Beach, Montenegro.

\section{INTRODUCTION}

Springtails (Insecta: Collembola) communities have been shown to vary in abundance and species composition according to changes in vegetation and soil conditions (Hågvar, 1982; Ponge, 1993; Chagnon et al., 2000). Soil acidity, mainly through associated changes in food and habitat, but also through chemical composition or osmolarity of the soil solution may favor or disfavor some species (Hågvar \& Abrahamsen, 1984; Vilkamaa \& Huhta, 1986; Salmon \& Ponge, 2002), and pH 5 has been noted as a landmark between two distinct types of communities (Ponge, 1993). The opposition between grassland and woodland can also be traced by the species composition of springtails population (Gisin, 1943; Rusek, 1989; Ponge, 1993). As a whole, Collembola are highly tolerant to a wide range of environmental conditions, including agricultural and industrial pollution, but species differ in their sensitivity to environmental stress (Lebrun, 1976; Prasse, 1985; Sterzyńska, 1990).

The springtails biodiversity in Montenegro is poorly investigated. Till now the Collembola fauna was studied in the surrounding area of fishing village Bigova, on the south coast of Trašte Bay. A total number of 16 Collembola species was noted classified in 5 families and 11 genera (Bogojević, 1978).

Collembolan fauna of Yugoslavia (Serbia and Montenegro) is a rich and diverse; total number of 233 species is known in Serbia. They are classified in 43 genera and 5 families. 89 species were recorded. In Montenegro classified in 10 genera and

* Corresponding author: tatjana.jaksic@pr.ac.rs BIOLOGY
7 families. 28 species and subspecies are endemic for Serbia $(12,02 \%)$ and 11 for Montenegro (12,36\%). Most of the endemic and relict forms live in caves, but some of them inhabits forests and cultivated steppe. Two centers of endemic Collembola differentiations are recognized in Yugoslavia: northern and eastern part (eastern Serbia) and the second one in the south and west (Montenegro, western and south-western Serbia) (Ćurčić \& Lučić, 1997). According to Ćurčić et al., (2008), 8 springtails cave species have been recorded in Montenegro.

The aim of this study is to identify and evaluate collembolan fauna in selected microhabitat that are situated near the Bečići Beach and mostly under influence of human activities.

\section{MATERIAL AND METHODS}

The collembolan specimens concidered herein were collected in the region of Bečići Beach (Figure 1), Montenegro from four different microhabitats.

Samples were taken from four locations: Hotel "Tara", Church "Sveti Toma" (St. Thomas), Hotel "Naftagas" and "Zelena Stena" (Green Rock) and from four different microhabitats. On the first site, sampling was done under the palm tree (Phoenix canariensis Chabaud). This site is under the firm influence of human activities. These include regular grass cutting, watering and probably occasional fertilization. On the second site samples were taken under the cypresses tree (Cupressus sempervirens L.). This sampling spot if facing south and exposed to the direct sun influence. On the third site, samples were taken from two microhabitats: under the larch tree (Larix decidua Mill.) and white pine (Pinus sylvestris L.) and on 
the fourth site under the white pine tree pine (Pinus sylvestris L.). Samples were taken in May, during the rainy season and September 2015, after the drought season for each location, and results were presented as qualitative findings.

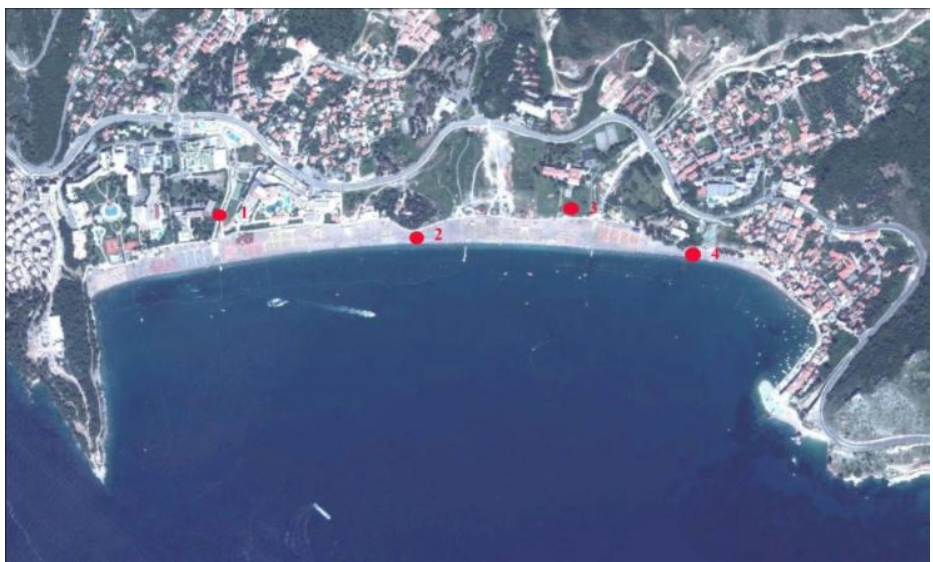

Figure 1. Bečići Beach with studied sites: 1. Hotel "Tara", 2. "St. Thomas" Church, 3. Hotel "Naftagas", 4. Green Stone.

Total number of 8 samples was collected. The soil samples, all together with leaf-litter was dimension $10 \mathrm{X} 10 \mathrm{X} 10 \mathrm{~cm}$. Soil animals were separated using modified Berlese-Tullgren funnel. Collembola specimens were separated and preserved in $75 \%$ ethyl-alcohol with few drops of glycerin. The slides were mounted in DPX. It was studied using KRÜSS MML 1204 (400X magnification) and TENSION EUMC 1600 (1000X magnification) microscopes. Identification was done using following dichotomous keys: Gisin (1960), Stach (1956), Stach (1960), Stach (1963) and Bellinger et al., (2015) Checklist of the Collembola of the world. Available from http:/www.collembola.org.

Specimens at the present are deposited in the collection of the Faculty of Sciences and Mathematics, University of Priština with settlement in Kosovska Mitrovica.

\section{RESULTS AND DISCUSSION}

Total number of 30 species of Collembola were identified, classified into six families and 17 genera at all of four investigated sites. (Table 1).

Site 1- „Tara“ Hotel

Site is situated nearby, Tara" Hotel in Boreti, coordinates $\mathrm{N}:$ 42.282628, E: 18.863026. The microhabitat investigated here was the area surrounding the palm tree Phoenix canariensis. This site is under the firm influence of human activities with shallow and hard soil with little litter. These include regular grass cutting, watering and probably occasional fertilization. Beside several species of mites and spiders, we have identified 11 Collembola species: Neanura muscorum MacGillivray, 1893, Bilobella mahunkai Danyi, 2010, Anurida maritima Guérin-Méneville, 1836, Hypogastrura viatica Tullberg, 1872, H. distincta Axelson, 1902, Onychiurus sp., Isotomurus alticolus Handschin, 1919, Isotomurus italicus Carapelli, A., Frati, F., Fanciulli, P.P. et Dallai, R., 1995, I. stuxbergi Tullberg, 1877, Isotoma riparia Nicolet, 1842, and Entomobrya multifasciata Tullberg, 1821. The abundance of the collembolan community was very low. A total of 38 collembolan individuals were counted in both samples with the dominance of Isotomurus genera.

Mites and spiders were abundant in the sample, and few insects' larvae were present.

Site 2- "St. Thomas" Church

Site 2 was chosen as specific place with cypresses trees community, coordinates: N: 42.281302, E: 18.870366 . There is no significant human activities in the sense of grass cutting, watering, fertilization, etc.. The sampling spot is facing south and thus exposed to the direct sun influence and very close to the beach itself. The halophyte-psammophyte vegetation was present and tipical foredune zone. Total number of 6 springtails species was identified: Hypogastrura viatica Tullberg, 1872, H. distincta Axelson, 1902, H. purpurescens Lubbock, 1870, Onychiurus sp., Isotomurus alticolus Handschin, 1919 and Sminthurus hispanicus Nayrolles, 1995. Collembolan community was abundant, with the highest diversity, richness and equitability of species from Hypogastrura family that is in compliance with Fernandes et al., (2009) for foredune zone.

There were very few mites and spiders present in the sample. One representative of Scorpiones order and one of Pseudoscorpiones order were present. Polyxenus lagurus L., 1758 (Diplopoda) has also been identified in this sample.

Site 3- "Naftagas" Hotel

Site 3 is located nearby "Naftagas" Hotel in Bečići, coordinates: $\mathrm{N}:$ 42.282234, E: 18.874273. Two different microhabitats were investigated at this site: under the larch tree and white pine tree. The larch tree microhabitat was similar to the site 1 and 7 collembolan species were common for these two sites (Table 1). The soil was hard with little litter. 9 collembolan species have been identified at this spot: Hypogastrura viatica Tullberg, 1872, H. purpurescens Lubbock, 1870, Isotomurus alticolus Handschin, 1919, I. fucicolus Axelson, 1906, I. italicus Carapelli, A., Frati, F., Fanciulli, P.P. et Dallai, R., 1995, I. stuxbergi Tullberg, 1877, Folsomia quadrioculata Tullberg, 1871, Entomobrya multifasciata Tullberg, 1821 and Cyphoderus bidenticulatus Börner, 1903 with the dominance of species from Isotomurus genera. From the same site, but second microhabitatunder the white pine tree, similar to the "Green Stone" site, but not so close to the beach, 12 collembolan species have been identified: Neanura muscorum MacGillivray, 1893, Pseudachorutes parvulus Börner, 1901, Hypogastrura viatica Tullberg, 1872,, H. distincta Axelson, 1902,, H. purpurescens Lubbock, 1870 , Onychiurus sp., Isotomurus alticolus Handschin, 1919, I. fucicolus Axelson, 1906, I. italicus Carapelli, A., Frati, F., Fanciulli, P.P. et Dallai, R., 1995, I. stuxbergi Tullberg, 1877, Entomobrya muscorum Nicolet, 1842 and E. nicoleti Lubbock, 1870. 10 species were common with site 4 with the same 
microhabitat. Total number of (Table 1) the species identified was 15 for both microhabitats, out of which six were common.

Table 1. Collembola species on studied sites at Bečići beach

\begin{tabular}{|c|c|c|c|c|c|c|}
\hline \multicolumn{2}{|c|}{ Collembola $\quad$ Sites } & \multirow[t]{2}{*}{$\begin{array}{l}\text { "Tara" Hotel } \\
\text { Palm tree }\end{array}$} & \multirow[t]{2}{*}{$\begin{array}{l}\text { "St. Thomas" } \\
\text { Cypresses tree }\end{array}$} & \multirow[t]{2}{*}{$\begin{array}{c}\text { "Naftagas" } \\
\text { Hotel } \\
\text { White pine tree } \\
\end{array}$} & \multirow[t]{2}{*}{$\begin{array}{l}\text { "Naftagas" } \\
\text { Hotel } \\
\text { Larch tree } \\
\end{array}$} & \multirow[t]{2}{*}{$\begin{array}{l}\text { Green Rock } \\
\text { White pine tree }\end{array}$} \\
\hline Familia & Species & & & & & \\
\hline \multirow[t]{8}{*}{$\begin{array}{l}\text { Neanuridae } \\
\text { Börner, } 1901\end{array}$} & $\begin{array}{l}\text { Neanura muscorum } \\
\text { MacGillivray, } 1893\end{array}$ & + & & + & & + \\
\hline & Bilobella mahunkai Danyi, 2010 & + & & & & \\
\hline & $\begin{array}{l}\text { Anurida maritima Guérin- } \\
\text { Méneville, } 1836\end{array}$ & + & & & & + \\
\hline & Anurida granaria, Tullberg, 1869 & & & & & + \\
\hline & \begin{tabular}{|l|} 
Pseudachorutes palmiensis \\
Börner, 1903 \\
\end{tabular} & & & & & + \\
\hline & $\begin{array}{l}\text { Pseudachorutes parvulus Börner, } \\
1901\end{array}$ & & & + & & \\
\hline & Xenylla grisea Axelson, 1900 & & & & & + \\
\hline & Xenylla maritima Tullberg, 1896 & & & & & + \\
\hline \multirow[t]{5}{*}{$\begin{array}{l}\text { Hypogastrurida } \\
\text { e Börner, } 1901\end{array}$} & \begin{tabular}{|l} 
Ceratophysella bengtssoni Ågren, \\
1904
\end{tabular} & & & & & + \\
\hline & $\begin{array}{l}\text { Ceratophysella succinea Gisin, } \\
1949\end{array}$ & & & & & + \\
\hline & \begin{tabular}{|l|} 
Hypogastrura viatica Tullberg, \\
1872
\end{tabular} & + & + & + & + & + \\
\hline & $\begin{array}{l}\text { Hypogastrura distincta Axelson, } \\
1902\end{array}$ & + & + & + & & + \\
\hline & $\begin{array}{l}\text { Hypogastrura purpurescens } \\
\text { Lubbock, } 1870\end{array}$ & & + & + & + & + \\
\hline $\begin{array}{l}\text { Onychiuridae } \\
\text { Lubbock, } 1876\end{array}$ & Onychiurus sp. & + & + & + & & \\
\hline \multirow[t]{7}{*}{$\begin{array}{l}\text { Isotomidae } \\
\text { Schäffer, } 1896\end{array}$} & $\begin{array}{l}\text { Isotomurus alticolus Handschin, } \\
1919\end{array}$ & + & + & + & + & + \\
\hline & \begin{tabular}{|l|} 
Isotomurus fucicolus Axelson, \\
1906
\end{tabular} & & & + & + & + \\
\hline & $\begin{array}{l}\text { Isotomurus italicus Carapelli, A., } \\
\text { Frati, F., Fanciulli, P.P. et Dallai, } \\
\text { R., } 1995\end{array}$ & + & & + & + & + \\
\hline & \begin{tabular}{|l|} 
Isotomurus stuxbergi Tullberg, \\
1877 \\
\end{tabular} & + & & + & + & + \\
\hline & Isotoma riparia Nicolet, 1842 & + & & & & + \\
\hline & Isotoma viridis Bourlet, 1839 & & & & & + \\
\hline & $\begin{array}{l}\text { Folsomia quadrioculata Tullberg, } \\
1871\end{array}$ & & & & + & \\
\hline \multirow[t]{7}{*}{$\begin{array}{l}\text { Entomobryidae } \\
\text { Schäffer, } 1896\end{array}$} & \begin{tabular}{|l|} 
Orchesella flavescens Bourlet, \\
1839 \\
\end{tabular} & & & & & + \\
\hline & \begin{tabular}{|l|} 
Entomobrya muscorum Nicolet, \\
1842
\end{tabular} & & & + & & + \\
\hline & Entomobrya albanica Stach, 1922 & & & & & + \\
\hline & \begin{tabular}{|l|} 
Entomobrya multifasciata \\
Tullberg, 1821
\end{tabular} & + & & & + & \\
\hline & \begin{tabular}{|l} 
Entomobrya nicoleti Lubbock, \\
1870
\end{tabular} & & & + & & + \\
\hline & \begin{tabular}{|l|} 
Lepydocyrtus lusitanicus $\mathrm{da}$ \\
Gama, 1964
\end{tabular} & & & & & + \\
\hline & \begin{tabular}{|l|} 
Cyphoderus bidenticulatus \\
Börner, 1903
\end{tabular} & & & & + & \\
\hline \multirow[t]{2}{*}{$\begin{array}{l}\text { Sminthuriade } \\
\text { Lubbock, } 1862\end{array}$} & $\begin{array}{l}\text { Sminthurus hispanicus Nayrolles, } \\
1995\end{array}$ & & + & & & + \\
\hline & \begin{tabular}{|l|} 
Arropalithes caecus Tullberg, \\
1871
\end{tabular} & & & & & + \\
\hline
\end{tabular}


Under the white pine tree, two specimen of Polyxenus lagurus L., 1758 (Diplopoda) were registered, and abundant communities of ants, mites and insects' larvae.

\section{Site 4- Green Stone}

This site is situated close to popular place on Bečići Beach, so called „Green Stone“, coordinates: N: 42.280915, E: 18.878272. The microhabitat chosen for this site was under the white pine tree with humusly soil covered with litter in deep shadow. In the time of sampling, the site was fenced in order to protect construction works that haven't started at the time of sampling. Following springatils have been indentifid at this site: Neanura muscorum MacGillivray, 1893, Anurida maritima GuérinMéneville, 1836, A. granaria Tullberg, 1869 Pseudachorutes palmiensis Börner, 1903, Xenylla grisea Axelson, 1900 Xenylla maritima Tullberg, 1896, Ceratophysella bengtssoni Ågren, 1904, C. succinea Gisin, 1949, Hypogastrura viatica Tullberg, 1872, H. distincta Axelson, 1902, H. purpurescens Lubbock, 1870, Isotomurus alticolus Handschin, 1919, I. fucicolus Axelson, 1906, I. italicus Carapelli, A., Frati, F., Fanciulli, P.P. et Dallai, R., 1995, I. stuxbergi Tullberg, 1877, Isotoma riparia Nicolet, 1842, Isotoma viridis Bourlet, 1839, Orchesella flavescens Bourlet, 1839, Entomobrya muscorum Nicolet, 1842, E. albanica Stach, 1922, E. nicoleti Lubbock, 1870 , Lepydocyrtus lusitanicus da Gama, 1964, Sminthurus hispanicus Nayrolles, 1995 and Arropalithes caecus Tullberg, 1871, 24 species in total. Species from Hypogastrura genera were numerous, but there were also many individuals from Isotomurus genera at the site, with no domination of certain groups.

There were poor communities of other expected biological groups, as recorded on the previously sites; mites were present, but with small abundance.

\section{CONCLUSION}

The springtails (Insecta: Collembola) fauna has been investigated during May and September 2015 in at specific microhabitats near by Bečići Beach, Montenegro. Total number of 30 species out from 17 genera and 6 families have been recorded at four investigated sites.

The „Green Stone“ site had the reachest springtail diversity, with 24 species recorded. The poorest community was recorded at "St. Thomas" Church site, 6 species in total.. At the same time, population density was high, predominated by representatives of the Hypogastruridae family. 11 species were recorded at „Tara“ Hotel site. The soil at the sampling site was shallow and hard, with occasional watering of the palm trees during the drought. Diverse community was recorded at the „Naftagas“ Hotel site with 15 recorded species, out of which six were common at both investigated microhabitats.

Hypogastruridae family had the biggest share in the Collembola community at the all of studied sites.. At the "Green Stone" site, although the richest with the number of the species, no group was dominant, but the community was unified.
Representatives of the family Hypogastruridae and Isotomidae were recorded at all of the studied sites, while representatives of the families: Naenuridae, Onychiuridae, Entomobryidae and Sminthuridae were present on some of locations.

\section{REFERENCES}

Bellinger, P.F., Christiansen, K. A., Janssens, F. Checklist of the Collembola of the world. Available from: http://www.collembola.org

Bogojević, J. 1978. Prilog poznavanju faune Collembola Crnogorskog primorja. Glasnik Prirodnjačkog muzeja. Beograd, Vol. 33, pp.157-161.

Chagnon, M., Hébert, C., Paré, D. 2000. Community structure of Collembola in sugar maple forest: relation to humus type and seasonal trends. Pedobiologia, 44, pp. 148-174.

Ćurčić, B.P.M. \& Lučić, L.R. 1997. On the Biodiversity of Springtails (Collembola, Insecta) in Yugoslavia (Serbia and Montenegro). Arch. Biol. Sci. Belgrade, 49, pp. 13-14.

Ćurčić, B.P.M., Decu, V., Juberthie, C. 2008. Cave-dwelling Invertebrates in Montenegro. Advences in arachnology and Development Biology. Monographs, 12, pp. 35-55. ViennaBelgrade-Sofia.

Fernandes, L.H., Nessimian, J.L., Mendonça, M.C. 2009. Structure of Poduromorpha (Collembola) communities in "resting" environments in Brazil. Pesquisa Agropecuária Brasileira, Brasília, 44 (8), pp. 1033-1039.

Gisin, H. 1943. Öcologic und Lebengemeinschaften der Collembolen im schweizerischen Exkusionsgebiet Basels. Revue Suisse de Zoologic, 50, pp. 131-224.

Gisin, H. 1960. Collembolenfaunae Europas. Museum D'Historie Naturelle. Geneve, pp. 312.

Hågvar, S. 1982. Collembola in Norwegian coniferous forest soil. I. Relation to plant communities and soil fertility. Pedobiologia, 24, pp. 255-296.

Hågvar, S. \& Abrahamsen, G. 1984. Collembola in Norwegian coniferous forest soil. III. Relation to soil chemistry. Pedobiologia, 27, pp. 331-339.

Lebrun, P. 1976. Effects écologiques de la pollution atmosphérique sur les populations et communaotés de microarthropodes corticoles (Acariens, Collemboles et Ptérygotes). Bull. Soc. Ecol. 7, pp. 417-430.

Ponge, J.F. 1993. Biocenoses of Collembola in atlantic temperate grass-woodland ecosystems. Pedobiologia, 37(4), pp. 223244.

Prasse, I., 1985. Indications of structural changes in the communities of microarthropods of the soil in an agroecosystem after applying herbicides. Agriculture, Ecosystems and Environment 13, pp. 205-215.

Rusek, J., 1989. Collembola and Protura in a meadow-forest ecotone. In: Dallai, R. (Ed.), Third Seminar on Apterygota. University of Siena, Siena, pp. 413-418.

Salmon, S., Ponge, J.F., Van straalen, N.M., 2002. Ionic identity of pore water influences $\mathrm{Ph}$ preference in Collembola. Soil Biology and Biochemistry 34, pp. 1663-1667.

Stach, J. 1956. The Apterygoten fauna of Poland in relation to the World fauna of this group of insects. Sminthuridae. Krakow. 
Stach, J. 1960. The Apterygoten fauna of Poland in relation to the World fauna of this group of insects. Tribe: Orchesellini. Krakow.

Stach, J. 1963. The Apterygoten fauna of Poland in relation to the World fauna of this group of insects. Tribe: Entomobryini. Krakow.
Sterzyńska, M. 1990. Communities of Collembola in natural and transformed soils of the linden-oak-hornbeam sites of the Mazovian Lowland. Fragmenta Faunistica, 34, pp. 165-262.

Vilkamaa, P. \& Huntha, V. 1986. Effects of fertilization and $\mathrm{Ph}$ on communities in pine forest soil. Ann. Zool. Fenn. 23, pp. 167-174. 